CARPATHIAN JOURNAL OF FOOD SCIENCE AND TECHNOLOGY

journal homepage: http://chimie-biologie.ubm.ro/carpathian_journal/index.html

\title{
PERFORMANCE EDIBLE COATING CONTAINING OLEORESIN FROM GINGER EMPRIT (ZINGIBER OFFIVINALE VAR. AMARUM) AND ITS EFFECT ON CONSUMER PREFERENCE PROPERTIES
}

\author{
Okta Pringga Pakpahan ${ }^{1}$, Citra Anggita², Siska Cahyanti², Desiana Nuriza Putri ${ }^{1 *}$, and Saskia \\ Agnes Monica ${ }^{2}$ \\ ${ }^{1}$ Department of Food Science and Technology, Agriculture and Animal Science Faculty, University of \\ Muhammadiyah Malang, Jl. Tlogomas No.246, Malang, Jawa Timur, Indonesia \\ ${ }^{2}$ College of Food Science and Technology, Agriculture and Animal Science Faculty, University of \\ Muhammadiyah Malang, Jl. Tlogomas No.246, Malang, Jawa Timur, Indonesia \\ *desiana@umm.ac.id
}

https://doi.org/10.34302/crpjfst/2019.11.3.15

\begin{tabular}{|c|c|}
\hline Article history: & " ABSTRACT \\
\hline $\begin{array}{l}\text { Received: } \\
\text { 1 January } 2019 \\
\text { Accepted: } \\
\quad 2 \text { August } 2019\end{array}$ & $\begin{array}{l}\text { Ginger oleoresin (GO) as natural compounds becoming widely used to } \\
\text { edible film, and coating for extending shelf life product. The objective of } \\
\text { this study was to investigate the performance oleoresin and accept of } \\
\text { consumer sensory properties from ginger emprit. Preliminary UHPLC-MS }\end{array}$ \\
\hline $\begin{array}{l}\text { Keywords: } \\
\text { Ginger Oleoresin; } \\
\text { Food Microbiology; } \\
\text { Shelf life; } \\
\text { Edible; } \\
\text { Meatball. }\end{array}$ & $\begin{array}{l}\text { assay analysis showed that most components of oleoresin }(24.7 \%) \text { geranial } \\
\text { and then gingerdione (10.2\%). The methods were active concentration } 1 \% \text {, } \\
1.5 \% \text { and } 2 \% \text { (wt) GO applied onto edible coating toward beef meatballs. } \\
\text { The resulting minimum inhibitory showed GO } 1.5 \% \text { was the optimum } \\
\text { concentration against Gram-positive bacteria (S. aureus) } 4.3 \mathrm{~mm} \text { and Gram- } \\
\text { negative bacteria (Salmonella) } 0.5 \mathrm{~mm} \text {. During the storage period, minimum } \\
\text { meatballs quality was determined based on microbiological (Total Plate } \\
\text { Count/TPC) and pH. Meatballs with edible containing GO } 1.5 \% \text { preserve } \\
\text { the best quality with resulted in } 1.83 \mathrm{log} \text { reduction of TPC and average pH } \\
\text { value at } 5.7 \text {. On sensory properties, the attribute was colour, taste, flavour } \\
\text { intensity, juiciness, and hardness. Only } 2 \% \text { GO concentration has a negative } \\
\text { effect on colour. }\end{array}$ \\
\hline
\end{tabular}

\section{Introduction}

In Indonesia, meatball or known as 'bakso' is popular street food. The consumption of meatball has increased by $18.5 \%$ over the last decades due to the relatively convenient purchase and availability (Kurniati et al, 2014; Purnomo \& Rahardiyan, 2008). Currently, in Indonesia food adulteration is a major issue in the meatball household-firm and is causing concerns among consumers and local food authority (Rahmania et al, 2015). The presence of prohibited chemical material in food products to gain economic benefits are serious matters in view of consumer health and protection. One of the major authenticity issues of household-firm meatball product using the prohibited material (e.g formalin, borax) for shelf life extension (Ministry of Health, 2017).

Meatball is contained high protein which prompt transforms the meatball to be a susceptible product for the growing of pathogenic and spoilage microorganisms (Kerry et al., 2006). The edible coating is simple method have been developed for shelf life extension to inhibit the growth of undesirable microorganisms and reduce lipid oxidation in the meat-based product. Recently, a variety of 
plant resource such as oleoresin for antimicrobial compound applied in edible coatings or films have been developing for application in fresh red meat, fish products and processing food (Horita et al., 2018; Granato, Nunes, \& Barba, 2017; Nikmaram et al., 2017; Lorenzo, Batlle, \& Gómez, 2014). The oleoresins characteristic is dark brown oil has an unstable mixture of essential oils and resin, nonvolatile components that are hydrophobic, and lipophilic in the form of viscous liquids lifting specific scent plant or herbs obtained by extraction (Yasni, 2017).

There are numerous studies on isolation and activities of ginger oleoresins deals with chemistry reactions (Singh et al., 2008; Babu et al.,2018), and anti-bacterial (Auta et al., 2011; Park et al., 2008; Shahidi and Hossain, 2018); however, indigenous ginger from Indonesia emprit (Zingiber Offivinale var. Amarum) are not studied so vastly. The purpose of the present study was to investigate ginger emprit oleoresin as alternative antimicrobial agents, against Gram-negative bacteria (Salmonella) and Grampositive bacteria (S. aureus) and evaluate the effects of using oleoresin when incorporated in beef meatball based coating toward consumer sensory properties. Our goal to find a simple adopting compound and method which can be done by household firms.

\section{Materials and methods}

\subsection{Materials and Media culture}

The mature and healthy of ginger emprit (Zingiber officinale var. Amarum) were bought from the local market in Malang City, Indonesia. Fresh beef meatball were purchased from household firms.

Glycerol, sulfuric acid $\left(\mathrm{H}_{2} \mathrm{SO}_{4}\right)$, Boric acid, $\mathrm{NaOH}$ and Petroleum ether used were of analytical grade were purchased from Merck (Darmstadt, Germany). The inhibition zone tests using culture medium of Nutrient agar Merck (Darmstadt, Germany) and resazurin Sigma Aldrich (Missouri, USA) as a metabolic indicator. Clinical isolated pathogenic Salmonella and S.aureus were purchased from Medical Laboratory (University of Muhammadiyah Malang).

\subsection{Preparation of oleoresin extraction}

The simplicial form ginger was properly weighed to 200 gr put into a beaker glass then added 1L $96 \%$ ethanol. The beaker glass perfectly preserved from light and evaporation. The stirring inside the beaker glass was achieved magnetically at $200 \mathrm{rpm}$ for 6 hours. After the extraction, samples were filtrated by a Buchner funnel and Whatman filter paper $42 \mathrm{mn}$ and the remaining solvent was removed by rotary evaporation at $50{ }^{\circ} \mathrm{C}$ for $20 \mathrm{~min}$ (FernándezRonco et al, 2008; Singh et al., 2008). The obtained light yellow colored oil with a pleasant odor was dried over anhydrous sodium sulfate yield was then calculated as the grams and stored in sealed vials at $\left(4 \pm 2{ }^{\circ} \mathrm{C}\right)$ in dark for further use and UPLC-MS analysis.

\subsection{Analysis of chemical oleoresins presumptive composition}

Ginger oleoresin components identification and presumptive amount present were determined by using UHPLC-MS (Angler Laboratory, Surabaya, Indonesia). Operated in negative ion mode in a capillary temperature of $100^{\circ} \mathrm{C}$, gas atomizer with a flow rate of 25 $\mathrm{L} /$ hour, the source of voltage $+2.9 \mathrm{kV}$ in full scan mode (range $100-700 \mathrm{~m} / \mathrm{z}$ ) at $30^{\circ} \mathrm{C}$ temperature, an Acquity UPLC BEH C18 (2.1 $\mathrm{mm} \times 50 \mathrm{~mm}, 1.7 \mathrm{~m}$; Waters, USA). 
Tabel 1. Presumptive identification of the components in ginger oleoresin

\begin{tabular}{|c|l|l|l|r|}
\hline $\begin{array}{c}\mathrm{t}_{\mathrm{R}} \\
(\mathrm{min})\end{array}$ & Molecular Formula & Compounds & $\begin{array}{l}\text { Fragments } \\
(\mathrm{m} / \mathrm{z})\end{array}$ & $\begin{array}{l}\text { Concentration } \\
(\text { Peak \%) }\end{array}$ \\
\hline 1.26 & $\mathrm{C}_{6} \mathrm{H}_{14} \mathrm{NO}_{5}$ & Glucosamine & 180.0866 & 0.3 \\
\hline 3.51 & $\mathrm{C}_{10} \mathrm{H}_{16} \mathrm{O}$ & Geranial & 224.0716 & 24.7 \\
4.43 & $\mathrm{C}_{10} \mathrm{H}_{12} \mathrm{O}_{2}$ & Eugenol & 237.1119 & 36.8 \\
\hline 5.1 & $\mathrm{C}_{17} \mathrm{H}_{26} \mathrm{O}_{4}$ & 6-Gingerol & 293.1757 & 8.9 \\
\hline 5.7 & $\mathrm{C}_{17} \mathrm{H}_{24} \mathrm{O}_{4}$ & Gingerdione & 291.1599 & 10.2 \\
\hline 6.32 & $\mathrm{C}_{17} \mathrm{H}_{24} \mathrm{O}_{3}$ & 6-Shogaol & 275.1651 & 4.7 \\
\hline 6.42 & $\mathrm{C}_{19} \mathrm{H}_{30} \mathrm{O}_{5}$ & 5-Acetoxy-6-gingerdiol & 337.2008 & Trace \\
\hline 7.40 & $\mathrm{C}_{23} \mathrm{H}_{34} \mathrm{O}_{4}$ & Dehydro-12-gingerdione & 373.2375 & 7.8 \\
\hline 9.25 & $\mathrm{C}_{19} \mathrm{H}_{32} \mathrm{ON}_{5}$ & 2,2-Dimethoxyethyl & 368.2431 & Trace \\
\hline \multicolumn{2}{|l}{} & & $93.7 \%$ \\
\hline
\end{tabular}

A ternary gradient elution consisting of $0.1 \%$ (v/v) formic acid in water (system A) and $0.1 \%$ $(\mathrm{v} / \mathrm{v})$ formic acid in acetonitrile (system B), at a flow rate of $0.2 \mathrm{~mL}$. min-1 with injection volume of $5 \mu \mathrm{L}$. Mass data were processed by the MassLynx V4.1 software.

\subsection{Disc diffusion}

Both pathogenic strains were cultured in nutrient broth for activation at $37{ }^{\circ} \mathrm{C}$ for $24 \mathrm{~h}$. Afterwards, inoculation into nutrient agar discs which aseptically prepared with the spread plate method. Then, put over sterilized Whatman filter paper no. 1 with $5 \mathrm{~mm}$ diameter has been dipped into $20 \mathrm{ml}$ of coating solutions containing GO with concentration $1 \%(1 \mu \mathrm{L} / 100$ $\mu \mathrm{L}), 1.5 \%(1.5 \mu \mathrm{L} / 100 \mu \mathrm{L})$, and $2 \%(2 \mu \mathrm{L} / 100$ $\mu \mathrm{L})$. The plates were incubated in an upright position at $37^{\circ} \mathrm{C}$, each plate is examined every next three days (3, 6, 9 and 12). The diameters of inhibition zones (in $\mathrm{mm}$ ) were measured (Seol et al., 2009; Noori et al. 2018).

\subsection{Preparation of coating solutions}

Crude ginger weighed $5 \mathrm{~g}$ dissolved in $100 \mathrm{ml}$ distilled water and stirred at a controlled temperature of $80^{\circ} \mathrm{C}$ and $1100 \mathrm{rpm}$ for $45 \mathrm{~min}$. $1.2 \mathrm{~g}$ (30\% wt of crude) glycerol was added as a plasticizer. Then, oleoresin was added with constant stirring to reach a final concentration of oleoresin 1 to $2 \%$ wt of crude ginger. After, 10 min stirring the solutions were applied for meatball dipped in a coating solution for 2 minutes and $1 \mathrm{~h}$ for dried.

\subsection{Meatball quality testing}

\subsubsection{Total Plate Colony (TPC)}

Samples $20 \mathrm{~g}$ were prepared aseptically and put into sterile plastic $180 \mathrm{ml}$ containing a sterile water mashed up by stomacher® $400 \mathrm{C}\left(10^{-1}\right)$ for $2 \min .1 \mathrm{~mL}$ of solution $10^{-1}$ dilution was taken by used micropipette and $2 \mathrm{~min}$ homogenized in $9 \mathrm{ml}$ sterile water $\left(10^{-2}\right)$ using vortex mixer, this step is repeated until reached $\left(10^{-6}\right)$ (Wasteson and Hornes, 2009). Serial dilutions $10^{-5}$ and $10^{-6}$ were taken $1 \mathrm{~mL}$ using the pour plate method on nutrient agar Merck (Darmstadt, Germany). All plates were incubated at $37^{\circ} \mathrm{C}$ for $48 \mathrm{~h}$, colonies data were transformed into logarithms of the number of colony forming units ( $\log \mathrm{CFU} / \mathrm{g}$ ).

\subsection{2. pH analysis}

Meatballs were measured using digital $\mathrm{pH}$ meter (SI analytics LAB 875) instrument after samples $(20 \mathrm{~g})$ have been homogenized in distilled water $(10 \mathrm{ml})$.

\subsubsection{Sensory evaluation}

Semi-trained 20 member panellists (13 females and 7 males) were selected from undergraduate students the department of food science and technology of the University of Muhammadiyah Malang evaluated the total acceptance of samples. Panelists were provided 
with an assessment form, plastic bowl, napkin, toothpick, a cup of water, and palate cleansers (plain crackers) to use between samples. All panelists had a background in beef meatball evaluation and were selected based on their sensitivity and limit detection of flavor intensity and taste concentrations of oleoresin. The attributes considered in the sensory evaluation were colour, taste, flavor intensity, juiciness, hardness and overall acceptability using 5 points descriptive scale, where $5=$ extremely desirable, $1=$ extremely undesirable and score of 3 was taken as the lower limit of acceptability.

\subsection{Statistical Analysis}

All experiments were performed in twice with analysis of variance (ANOVA) (SPSS Inc, Version 20) performed with a completely randomized design. Duncan's test $(\mathrm{p}<0.05)$ was used to detect differences among mean values of meatballs properties in all test intervals.

\section{Results and Discussions}

\subsection{Identification of the components in} ginger oleoresin

The Careful identification of GO emprit was carried out HPLC assay result which interpretation contains a specific large number of compounds in Table 1. From Table 1 it is evident that in $\mathrm{GO}$ existing four major components of 9 components constituting $93.7 \%$ of the total weight. Most of the findings have similarity with other variety of ginger (var. rubrum and var. officinale) which has been reported in previous study (Agrawal et al. 2001, Kamaliroosta et al. 2012 and Gurdip Singh et al 2008). The differences only on the amount, Singh et al. (2008) identified Eugenol (49.8) and geranial $(25.9 \%)$ in our study indicated amount Eugenol (36.8\%), geranial (24.7\%) and glucosamine trace $(0.3 \%)$ was rarely found in rhizome plants. While specific emperit comparison with Arijanti et al. (2019) identified 6-Gingerol have the main components of GO on Gingerol $1.8 \%$, Shogaol $0.10 \%$ and Zingerone $0.86 \%$. There are many factors could be drive differences in the chemical composition of GO such as genetic, production conditions, environmental, weather conditions, distillation conditions and other factors (Rehman et al., 2016; Blair et al., 2001).

\subsection{Antimicrobial activity testing}

The performance results from antimicrobial activity testing of GO against $\mathrm{S}$. aureus (Grampositive) and Salmonella (Gram-negative) has different effective concentration is shown in Fig 1. GO concentration starting at $1 \%$ $(1 \mu \mathrm{L} / 100 \mu \mathrm{L}), 1.5 \%(1.5 \mu \mathrm{L} / 100 \mu \mathrm{L})$, and $2 \%$ $(2 \mu \mathrm{L} / 100 \mu \mathrm{L})$ was found to be more susceptible to against Salmonella gram-negative.
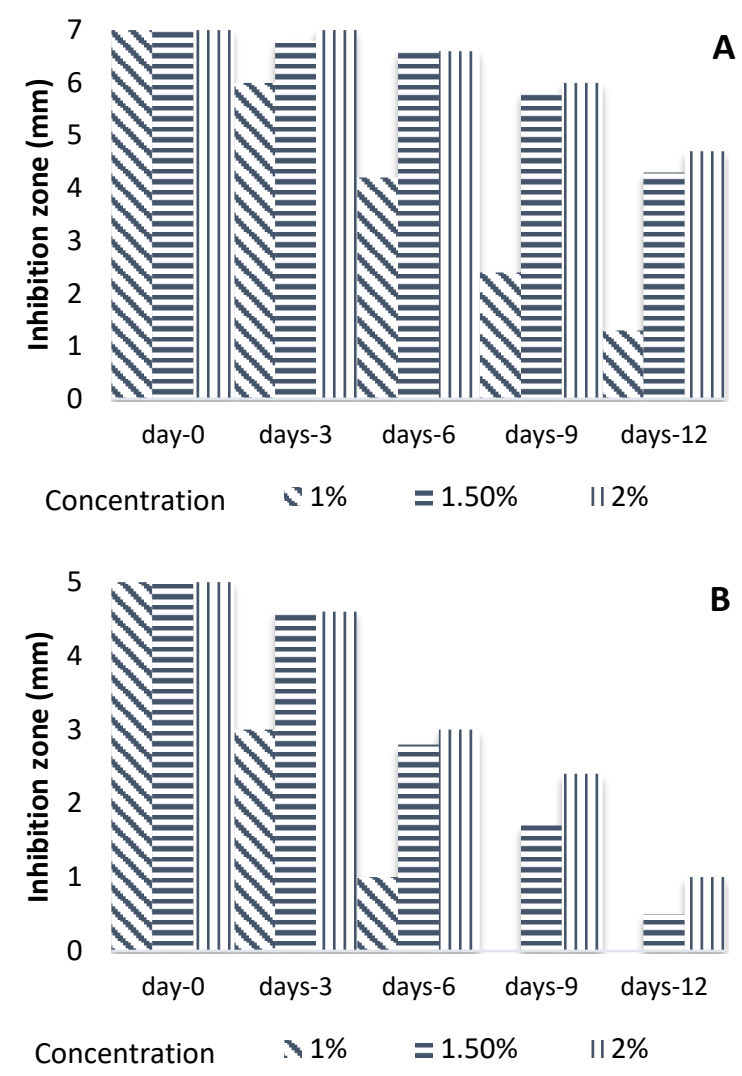

Figure 1. Anti-bacterial activity of meatball edible coatings containing ginger oleoresin against $\mathrm{S}$. aureus (A) and Salmonella (B). Data shown are the means \pm standard deviation $(\mathrm{P}<0.05)$.

The difference GO was comparatively more effective against $\mathrm{S}$. aureus gram-positive. This discrepancy of the higher resistance of gram- 
negative due to the cell wall structural have an outer membrane containing a thin peptidoglycan layer and lipopolysaccharide. It acts permeability barrier lead to reducing bioactive compounds activity by absorption of reactive oxygen species (ROS) thereby affecting the performance of GO (Russell, 2003). The intense inhibiting activity of GO against gram-positive could be due to interactions between principal component properties of phenolic compounds (Eugenol, geranial, gingerdione, 6-Gingerol and 6-shogaol) with the positive charged cell wall (Calo et al., 2015).

In the recently, GO study has been used to inhibit the activity of pathogens which the performance ability dependent on the concentration used to. Our finding, first treatment GO $1 \%(1 \mu \mathrm{L} / 100 \mu \mathrm{L})$ for $72 \mathrm{~h}$ storage (3 days) inhibiting activity by more than $90 \%$ for S. aureus and $65 \%$ for Salmonella. Although the GO $(1 \mu \mathrm{L} / 100 \mu \mathrm{L})$ be able to inhibit S. aureus for $288 \mathrm{~h}$ storage (12 days) but did not with Salmonella which is rotted in early $150 \mathrm{~h}$ storage for (6 days 4 hours). In contrast, increasing the GO concentrations to $1.5 \%(1.5 \mu \mathrm{L} / 100 \mu \mathrm{L})$, and $2 \%(2 \mu \mathrm{L} / 100 \mu \mathrm{L})$ reveal significant performance could inhibit up to $288 \mathrm{~h}$ (12 days) these two bacteria with a clear zone for S. aureus (4.3 and $4.7 \mathrm{~mm}$ ) and Salmonella $(0.7$ and $1.1 \mathrm{~mm})$.

Interestingly, even though sing et al (2008) study reported that GO is less effective against S. aureus in disc diffusion method. Furthermore, Mesomo et al (2013) result demonstrated that GO has slight inhibition activity against salmonella. However, from our data indicated GO from Emprit variant has high-performance and effect is comparable to chloramphenicol against these bacteria. This suggests that different variant ginger have different strength and characteristics of phenolic compounds which might responsible for inhibition performance.

\subsection{Beef meatballs quality testing 3.3.1. Total plate count (TPC)}

Total plate count (TPC) indicating the level of microorganism in it during storage study from 0 to 12 days. The control sample has increased significantly $(\mathrm{p}<0.05) 6.12 \mathrm{Log} \mathrm{CFU} / \mathrm{g}$ at 6 days, because it was completely putrefied was not recorded up to end of a storage.

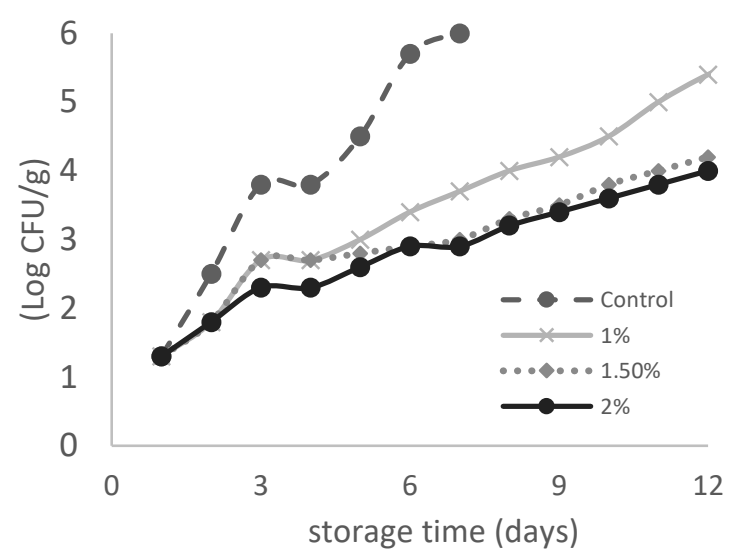

Figure 2. Effect of the edible coatings containing ginger oleoresin on the microbial growth (Log CFU/g) of total plate count (TPC) values in meatballs during storage at $4^{0} \mathrm{C} \pm 1^{0} \mathrm{C}$. Data shown are the means \pm standard deviation $(\mathrm{p}<0.05)$.

Addition of $1 \%(1 \mu \mathrm{L} / 100 \mu \mathrm{L})$ coated oleoresin into meatballs significantly decreased value the TPC $\pm 1.2 \log \mathrm{CFU} / \mathrm{g}$ up to 9 days. Higher addition of oleoresin into meatballs $1.5 \%$ $(1.5 \mu \mathrm{L} / 100 \mu \mathrm{L})$ to $2 \%(2 \mu \mathrm{L} / 100 \mu \mathrm{L})$ was significantly control the microbial growth of meatballs under $4.4 \log \mathrm{CFU} / \mathrm{g}$ at the end of storage time (12 days). Within this result, the meatball can be consumed according Indonesia National Standards which is TPC does not exceed $\log 1 \times 10^{5}$ CFU/g (SNI.3818:2014). Similar case on GO Noori et al (2018) result demonstrated the concentration treatment have significant effects inhibit the population of moulds and yeast on chicken breast fillets during storage.

More specific Widayat et al (2017) using liquid smoke containing Eugenol of GO could inhibit inactivates intracellular enzymes for forming process that causes the lysis on the cell wall of microbes. 
Table 2. Sensory properties of meatballs edible coating containing ginger oleoresin ( $n=20$ panelists)

\begin{tabular}{|c|c|c|c|c|c|c|c|}
\hline $\begin{array}{l}\text { Storage time } \\
\text { (Day) }\end{array}$ & $(\%)$ & Colour & Taste & $\begin{array}{l}\text { Flavour } \\
\text { Intensity }\end{array}$ & Juiciness & Hardness & Overall \\
\hline \multirow[t]{3}{*}{0} & 1 & $6.4 \pm 0.04$ & $6.0 \pm 0.63$ & $6.4 \pm 1.24$ & $6.2 \pm 2.07$ & $6.4 \pm 0.17$ & $6.0 \pm 0.77$ \\
\hline & 1.5 & $6.0 \pm 0.23$ & $5.9 \pm 0.08$ & $6.3 \pm 0.32$ & $6.0 \pm 1.13$ & $6.1 \pm 0.63$ & $6.0 \pm 0.33$ \\
\hline & 2 & $6.3 \pm 0.48$ & $5.9 \pm 0.15$ & $6.2 \pm 0.67$ & $6.0 \pm 0.01$ & $6.0 \pm 0.01$ & $6.0 \pm 0.61$ \\
\hline \multirow[t]{3}{*}{3} & 1 & $5.1 \pm 0.44$ & $5.9 \pm 0.27$ & $6.0 \pm 0.44$ & $6.2 \pm 1.20$ & $6.0 \pm 0.31$ & $6.0 \pm 0.11$ \\
\hline & 1.5 & $5.7 \pm 0.05$ & $5.5 \pm 0.85$ & $6.0 \pm 0.25$ & $6.0 \pm 0.12$ & $6.1 \pm 0.12$ & $6.0 \pm 0.22$ \\
\hline & 2 & $6.0 \pm 0.48$ & $5.7 \pm 0.16$ & $6.0 \pm 0.05$ & $6.0 \pm 0.31$ & $6.0 \pm 0.01$ & $6.0 \pm 0.90$ \\
\hline \multirow[t]{3}{*}{6} & 1 & $4.7 \pm 0.57$ & $4.0 \pm 0.21$ & $3.7 \pm 0.30$ & $6.0 \pm 0.53$ & $5.9 \pm 0.05$ & $5.8 \pm 0.05$ \\
\hline & 1.5 & $5.5 \pm 0.35$ & $5.5 \pm 0.17$ & $5.7 \pm 0.05$ & $5.9 \pm 0.17$ & $6.1 \pm 0.61$ & $6.0 \pm 0.12$ \\
\hline & 2 & $5.3 \pm 0.05$ & $5.1 \pm 0.25$ & $4.8 \pm 0.23$ & $5.9 \pm 0.90$ & $6.0 \pm 0.45$ & $6.0 \pm 0.91$ \\
\hline \multirow[t]{3}{*}{9} & 1 & & & & & & \\
\hline & 1.5 & $4.6 \pm 0.23$ & $3.7 \pm 0.63$ & $3.9 \pm 0.50$ & $5.7 \pm 0.54$ & $4.4 \pm 0.40$ & $5.2 \pm 0.84$ \\
\hline & 2 & $4.0 \pm 0.12$ & $3.4 \pm 0.05$ & $3.5 \pm 0.46$ & $5.5 \pm 0.12$ & $4.5 \pm 0.81$ & $5.1 \pm 0.13$ \\
\hline \multirow[t]{3}{*}{12} & 1 & & & & & & \\
\hline & 1.5 & $3.4 \pm 0.52$ & $3.6 \pm 0.22$ & $3.6 \pm 0.51$ & $4.9 \pm 0.13$ & $3.7 \pm 0.82$ & $4.3 \pm 0.10$ \\
\hline & 2 & $3.0 \pm 0.02$ & $2.0 \pm 0.47$ & $1.3 \pm 0.86$ & $4.8 \pm 0.22$ & $3.6 \pm 0.21$ & $4.0 \pm 0.92$ \\
\hline Control & & $6.6 \pm 0.01$ & $6.2 \pm 0.20$ & $6.3 \pm 0.08$ & $6.2 \pm 0.25$ & $6.7 \pm 0.25$ & $6.3 \pm 0.19$ \\
\hline
\end{tabular}

\subsection{2. pH Analysis}

The control samples had higher $\mathrm{pH}$ value ranged from 5.8 to 6.34 , while oleoresin treatment samples had the $\mathrm{pH}$ value ranged from 5.8 to 6.0 which is differed significantly $(\mathrm{p}<.05)$. In line with these result, Sallam et al. (2004) study also findings storage time factor had a significant $(\mathrm{p}$ $<.05)$ influence on increasing of $\mathrm{pH}$ values. An increase may be attributed to protein degradation of metabolites by bacterial action in a beef meatball (Karabagias et al. 2011) in this situation spoilage often produce highly malodorous volatile substances (Alfreider et al., 2002; Xiao et al. 2013).

\subsubsection{Sensory analysis}

Sensory analysis beef meatballs score showed that increased percentage additional oleoresin concentration and refrigerator storage time give effect toward less acceptable in panelist sensory qualities. The sensory preferences on color, taste, flavor intensity juiciness, and hardness levels significantly decreased $(\mathrm{p}<0.05)$ gradually up to end of the storage (12 days).

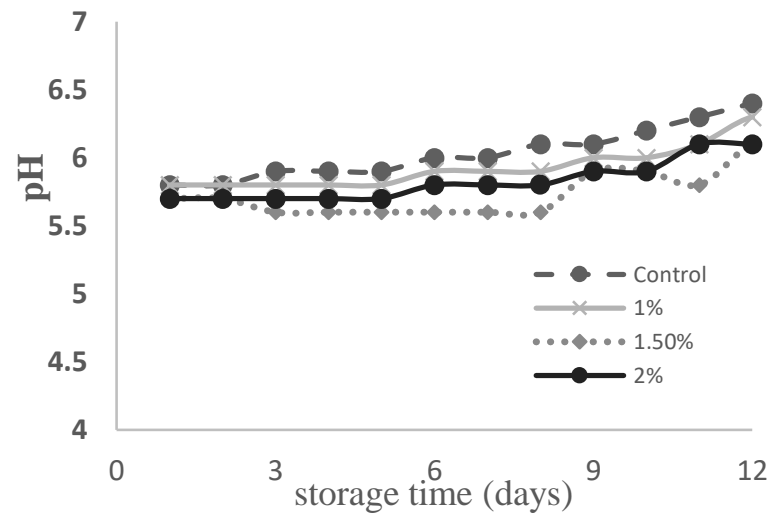

Figure 3. Effect of the edible coating containing ginger oleoresin on $\mathrm{pH}$ values in meatballs during storage at $4^{0} \mathrm{C} \pm 1^{0} \mathrm{C}$.

Except, oleoresin concentration $1 \%$ was not recorded at a day of 9 and 12 because it was completely rotted. In the current study, the colors difference of beef meatballs caused by ginger oleoresin negatively affected the sensory color and flavor intensity evaluation results samples with $2 \%$ had higher scores. However, it was evaluated this decrement of preference in color and flavor intensity did not have a negative effect and no significant differences ( $p>.05)$ were seen in taste, hardness and overall acceptance of the samples. These 
results are in conformity with a study conducted by Turgut et al., (2017) that the addition of pomegranate peel extract in beef meatballs during frozen storage was not a significant difference in terms of taste. Moreover, the taste of the beef with added kaffir lime leaves oleoresin did not induce a significant taste and juiciness of kaffir lime (Utami et al., 2014)

\section{Conclusions}

These results demonstrated and verified that oleoresins of ginger emprit had a potential antibacterial into beef meatball could help to improve shelf life without ignoring consumer preference. The negative impact come from color property which is not affected in taste, flavor intensity and overall acceptance scores. From the inhibit the growth of bacteria oleoresins as natural preservatives have a simple application and low-cost.

\section{References}

Alfreider, A., Peters, S., Tebbe, C. C., Rangger, A., \& Insam, H. (2002). Microbial Community Dynamics During Composting of Organic Matter as Determined by $16 \mathrm{~S}$ Ribosomal DNA Analysis. Compost Science \& Utilization, 10(4), 303-312. doi:10.1080/1065657x.2002.10702094.

Auta, A.A. Galadima, J.U. Bassey, O.D. Olowoniyi, O.O. Moses and A.B. Yako. (2011). Antimicrobial Properties of the Ethanolic Extracts of Zingiber officinale (Ginger) on Escherichia coli and Pseudomonas aeruginosa. Research Journal of Biological Sciences, 6 (1) 37-39. DOI: 10.3923/rjbsci.2011.37.39

Babu, G. D. Kiran., Dolma, S.K., Sharma, M and S. G. Reddy. (2018). Chemical composition of essential oil and oleoresins of Zingiber officinale and toxicity of extracts/essential oil against diamondback moth (Plutella xylostella), Toxin Reviews, (110). DOI:10.1080/15569543.2018.1491056
Bellik Y. (2014). Total antioxidant activity and antimicrobial potency of the essential oil and oleoresin of Zingiber officinale Roscoe. Asian Pacific Journal of Tropical Disease, 4(1), 40-44.

Blair, G.J, R Lefroy, A Whitbread, N Blair, and A Conteh. (2001). Assessment methods for soil carbon. Florida: Lewis Publishers (Chapter 22)

Bustamante, A., Masson, L., Velasco, J., del Valle, J. M., \& Robert, P. (2016). Microencapsulation of $\mathrm{H}$. pluvialis oleoresins with different fatty acid composition: Kinetic stability of astaxanthin and alpha-tocopherol. Food Chemistry, 190, 1013-1021. doi:10.1016/j.foodchem.2015.06.062.

Calo, J. R., Crandall, P. G., O’Bryan, C. A., \& Ricke, S. C. (2015). Essential oils as antimicrobials in food systems - A review. Food Control, 54, 111-119. doi:10.1016/j.foodcont.2014.12.040

Fernández-Ronco, M. P., Gracia, I., de Lucas, A., \& Rodríguez, J. F. (2012). Extraction ofCapsicum annuumOleoresin by Maceration and Ultrasound-Assisted Extraction: Influence of Parameters and Process Modeling. Journal of Food Process Engineering, 36(3), 343-352. doi:10.1111/j.1745-4530.2012.00702.x

Figueroa-Lopez, K. J., Andrade-Mahecha, M. M., \& Torres-Vargas, O. L. (2018). Spice oleoresins containing antimicrobial agents improve the potential use of bio-composite films based on gelatin. Food Packaging and Shelf Life, 17, 50-56. doi:10.1016/j.fpsl.2018.05.005

Granato, D., Nunes, D. S., \& Barba, F. J. (2017). An integrated strategy between food chemistry, biology, nutrition, pharmacology, and statistics in the development of 
functional foods: A proposal. Trends in Food Science \& Technology, 62, 13-22.

doi:10.1016/j.tifs.2016.12.010.

Horita, C. N., Baptista, R. C., Caturla, M. Y. R., Lorenzo, J. M., Barba, F. J., \& Sant'Ana, A. S. (2018). Combining reformulation, active packaging and non-thermal post-packaging decontamination technologies to increase the microbiological quality and safety of cooked ready-to-eat meat products. Trends in Food Science \& Technology, 72, 45-61. doi:10.1016/j.tifs.2017.12.003.

Jongsun Park, Jaejin Park, Suwang Jang, Seryun Kim, Sunghyung Kong, Jaeyoung Choi, Kyohun Ahn, Juhyeon Kim, Seungmin Lee, Sunggon Kim, Bongsoo Park, Kyongyong Jung, Soonok Kim, Seogchan Kang, and Yong-Hwan Lee, FTFD. (2008). an informatics pipeline supporting phylogenomic analysis of fungal transcription factors, Bioinformatics, 24 (7)1024-1025.

Doi.org/10.1093/bioinformatics/btn058

Karabagias, I., Badeka, A., \& Kontominas, M. G. (2011). Shelf life extension of lamb meat using thyme or oregano essential oils and modified atmosphere packaging. Meat Science, $\quad 88(1), \quad$ 109-116. doi:10.1016/j.meatsci.2010.12.010.

Kerry, J. P., O’Grady, M. N., \& Hogan, S. A. (2006). Past, current and potential utilisation of active and intelligent packaging systems for meat and muscle-based products: A review. Meat Science, 74(1), 113-130. doi:10.1016/j.meatsci.2006.04.024.

Kurniati, E., Rohman, A., \& Triyana, K. (2014). Analysis of lard in meatball broth using Fourier transform infrared spectroscopy and chemometrics. Meat Science, 96, 94-98. doi.org/10.1016/j.meatsci.2013.07.003.
Lorenzo, J. M., Batlle, R., \& Gómez, M. (2014). Extension of the shelf-life of foal meat with two antioxidant active packaging systems. LWT - Food Science and Technology, 59(1), 181-188. doi:10.1016/j.lwt.2014.04.061.

Mesomo, M.C., Corazza, M.L., Ndiaye, P.M., Santa, O.R., Cardozo, L., Scheera, A.P. (2013).Supercritical CO2 extracts and essential oil of ginger (Zingiber officinale R.): Chemical composition and antibacterial activity. The Journal of Supercritical Fluids 80,(44-49).

Doi.org/10.1016/j.supflu.2013.03.031.

Ministry of Health Republic Indonesia. (2018). Laporan Statistik survei bahan pangan

Nikmaram, N., Budaraju, S., Barba, F. J., Lorenzo, J. M., Cox, R. B., Mallikarjunan, K., \& Roohinejad, S. (2018). Application of plant extracts to improve the shelf-life, nutritional and health-related properties of ready-to-eat meat products. Meat Science, $145,245-255$. doi:10.1016/j.meatsci.2018.06.031.

Noori, S., Zeynali, F., \& Almasi, H. (2018). Antimicrobial and antioxidant efficiency of nanoemulsion-based edible coating containing ginger (Zingiber officinale ) essential oil and its effect on safety and quality attributes of chicken breast fillets. Food Control, 84, 312-320. doi:10.1016/j.foodcont.2017.08.015.

Purnomo, H., \& Rahardiyan, D. (2008). Review article: Indonesian traditional meatball. International Food Research Journal, 15, 101-108.

Rahmania, H., Sudjadi \& Rohman A. (2015). The employment of FTIR spectroscopy in combination with chemometrics for analysis of rat meat in meatball formulation. Meat Science, 100, 301-305. 
http://dx.doi.org/10.1016/j.meatsci.2014.10. 028.

Rehman, R., Hanif, M. A., Mushtaq, Z., \& AlSadi, A. M. (2015). Biosynthesis of essential oils in aromatic plants: A review. Food Reviews International, 32(2), 117-160.

Rolfe, S. A., Strelkov, S. E., Links, M. G., Clarke, W. E., Robinson, S. J., Djavaheri, Robert M, Parham H, Sateesh K, Parkin I. A. P. , Ali T and Borhan, M. H. (2016). The compact genome of the plant pathogen Plasmodiophora brassicae is adapted to intracellular interactions with host Brassica spp. BMC Genomics, 17(1). doi:10.1186/s12864-016-2597-2.

Russell, A. D. (2003). Similarities and differences in the responses of microorganisms to biocides. Journal of Antimicrobial Chemotherapy, 52(5), 750763. doi:10.1093/jac/dkg422.

Sallam, K. I., Ishioroshi, M., \& Samejima, K. (2004). Antioxidant and antimicrobial effects of garlic in chicken sausage. LWT - Food Science and Technology, 37(8), 849-855. doi:10.1016/j.lwt.2004.04.001.

Sayyad, SF and Chaudhari SR. 2010. Isolation of Volatile Oil from Some Plants of Zingiberaceae Family and Estimation of Their Antibacterial potential. Journal of Current Pharmaceutical. 4(1)1-3.

Seol, K.-H., Lim, D.-G., Jang, A., Jo, C., \& Lee, M. (2009). Antimicrobial effect of $\kappa$ carrageenan-based edible film containing ovotransferrin in fresh chicken breast stored at $5^{\circ} \mathrm{C}$. Meat Science, 83(3), 479-483. doi:10.1016/j.meatsci.2009.06.029.

Shahidi, F., \& Hossain, A. (2018). Bioactives in spices, and spice oleoresins: Phytochemicals and their beneficial effects in food preservation and health promotion. Journal of Food Bioactives, 3

(8-75).

Doi.org/10.31665/JFB.2018.3149.

Singh, G., Kapoor, I. P. S., Singh, P., de Heluani, C. S., de Lampasona, M. P., \& Catalan, C. A. N. (2008). Chemistry, antioxidant and antimicrobial investigations on essential oil and oleoresins of Zingiber officinale. Food and Chemical Toxicology, 46(10), 32953302. doi:10.1016/j.fct.2008.07.017.

Singh, G., Maurya, S., deLampasona, M. P., \& Catalan, C. A. N. (2007). A comparison of chemical, antioxidant and antimicrobial studies of cinnamon leaf and bark volatile oils, oleoresins and their constituents. Food and Chemical Toxicology, 45(9), 1650-1661. doi:10.1016/j.fct.2007.02.031.

Tao, Y., Li, W., Liang, W., \& Van Breemen, R. B. (2009). Identification and Quantification of Gingerols and Related Compounds in Ginger Dietary Supplements Using HighPerformance Liquid Chromatography-Tandem Mass Spectrometry. Journal of Agricultural and Food Chemistry, 57(21), 10014-10021. doi:10.1021/jf9020224.

Turgut, S. S., Işıkçı, F., \& Soyer, A. (2017). Antioxidant activity of pomegranate peel extract on lipid and protein oxidation in beef meatballs during frozen storage. Meat Science, 129, 111-119. doi:10.1016/j.meatsci.2017.02.019.

Utami, R., Kawiji, Khasanah, L.U. and Nasution, M.I.A. (2017). Preservative effects of kaffir lime (Citrus hystrix DC) leaves oleoresin incorporation on cassava starchbased edible coatings for refrigerated fresh beef. International Food Research Journal, 24(4), 1464- 1472.

Wasteson, Y, and Hornes, E. 2009. Pathogenic Escherichia Coli Found in Food. 
International Journal Of Food Microbiology, 12, 103-114.

W Widayat. W, Arifiani S.N, Yaqin. N and A.

N. Al Baarri. (2017). Study of utilization liquid smoke and carrageenan as a natural antibacterial in manufacturing beef meatballs. International Symposium on Food and Agro-biodiversity (ISFA). IOP Conferance. doi :10.1088/17551315/102/1/012060.

Xiao, S., Zhang, W. G., Lee, E. J., Ma, C. W., \& Ahn, D. U. (2013). Effects of diet, packaging, and irradiation on protein oxidation, lipid oxidation, and color of raw broiler thigh meat during refrigerated storage. Poultry Science, 90(6), 1348-1357. doi:10.3382/ps.201001244.

Yasni, S. (2018). Development technology of functional drinks made from ginger extracts as products model for developing smallmedium enterprises. IOP Conf. Ser.: Earth Environ. $\quad$ Sci. $196 \quad 01$. https://iopscience.iop.org/article/10.1088/17 55-1315/196/1/012017

\section{Acknowledgment}

This research was funded by a research grant the Ministry of Research, Technology and Higher Education No. 1020/B3.1/KM/2018. We would like thanks to Ms. Lisa Lisdiana for Chemical Analysis compounds. 